\title{
THE EFFECT OF THE EXTRACT OF RHIZOME AND ROOT OF HELLEBORE (HELLEBORUS ODORUS W. ET K.) ON PARAMETERS OF WHITE BLOOD COUNT AND DEGREE OF PHAGOCYTOSIS IN WISTAR RATS
}

DAVIDOVIĆ VESNA*, LAZAREVIĆ M**, JOKSIMOVIĆ-TODOROVIĆ MIRJANA*, MAKSIMOVIĆ Z*** and JOVANOVIĆ $\mathrm{M}^{* *}$

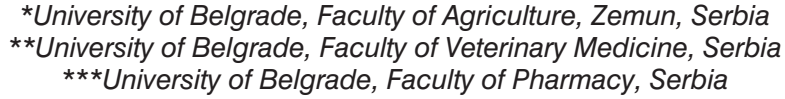

(Received 15th December 2009)

The objective of this research was to study the effects that the extract of rhizome and root of Helleborus odorus W. et $K$. (Ranunculaceae) can have on modifications in the parameter values of white blood cells count and degree of phagocytosis by peritoneal macrophages and neutrophil granulocytes in Wistar rats. The trial was conducted on 28 rats divided into 4 groups with 7 animals in each group. To the control group of rats sterile physiological solution in the quantity of $0.25 \mathrm{~mL} / 100 \mathrm{~g} \mathrm{BW}$ was applied intramuscularly. For the purpose of monitoring the effect of the extract of rhizome and root of hellebore (HE) during a time period, the HE was applied intramuscularly to rats in a dose of $10 \mathrm{mg} / 100 \mathrm{~g} \mathrm{BW}$, while the blood samples for analysis were taken after $24 h, 48 h$ and $72 h$.

The consequence of intramuscular application of HE was an increased count of total leukocytes in all trial groups, the most expressed leukocytosis being registered 24h after application of HE. Statistically significant higher value in the count and percent of neutrophil granulocytes in the blood was recorded $24 \mathrm{~h}$ after treatment in relation to the control and two other trial groups $(p<0.001)$, among which a statistical significance was not established. The extract of hellebore rhizome and root has led to lymphopenia, resulting in the increase of the neutrophil/limphocyte index in the trial groups $24 \mathrm{~h}$ and $48 \mathrm{~h}$ after treatment. The application of HE had no significant effect on the count of monocytes in treated animals. The applied extract has caused a significant increase in the degree of phagocytosis by residing peritoneal macrophages and neutrophil granulocytes in blood.

Key words: degree of phagocytosis, hellebore, hematological parametres, rats 


\section{INTRODUCTION}

In the health care of animals a single or combined medical herb substances are applied for the purpose of prophylaxis, treatment of the onset stages of disease or as a supplement in medical therapy. By application of herbal preparations it is possible to stimulate the functions of the immune system and potentiate its defensive capacities. In recent years, immunostimulatory activity has been reported in a number of medicinal and other plants (Mungantiwar et al., 1997; Makare et al., 2001; Goel et al., 2002; Schepetkin and Quinn, 2006).

A herbal drug Helleborus sp. is represented by a dried rhizome of dark brown to black colour, thickly overgrown by thin, dark grey roots (Hellebori rhizoma et radix), and is being extracted in spring or in autumn. Hellebori rhizoma et radix composed of various active components including bufadienolides (Wissner and Kating, 1974; Muhr et al., 1995), steroidal saponins (Ribár et al., 1986; Vladimirov et al., 1991), lipids (Colombo et al., 1991), ecdysones (Colombo and Tomè, 1993; Rosselli et al., 2009) and alkaloids (Slavík et al., 1987), has long been used in traditional folk veterinary medicine. Because of its irritating influence on skin and mucous membrane, the rhizom of hellebore is, in etnoveterinary medicine, used in "herbal treatment" for a great number of farm animals (horses, pigs, sheep). Unspecific irritable therapy by means of transcutaneous implant of hellebore rhizome is conducted for the purpose of prophylaxis in uninfected animals (Tucakov, 1996), immature animals and in cases of diminished appetite (Bogdan et al., 1989; 1990-a), as well as in acute stages of chronic diseases (Tosevski et al., 2004).

It was confirmed by a number of research studies that the extract of rhizome and root of hellebore displays stimulatory effects on the immuno system although some immunosuppressive effects were described, as well. Bolte et al. (1992) studied a proinflamatory influence of the extract of Helleborus sp. in rats, rabbits, horses and dogs and determined the inflammatory effect to be proportional to the given concentration, dose and way of application. The same authors mention some trial results that suggest the immunomodulatory influence of rhizome and root of Helleborus L. when applied simultaneously with antisalmonellosis vaccine in calves.

Bogdan et al. (1993) applied the extract of rhizome and root of $H$. purpurascens $\mathrm{W}$. et $\mathrm{K}$. to undeveloped fattening lambs with a complete metabolic disorder, and to sheep before their exposure to antigen. In lambs a significant increase in body mass and decrease in mortality rate was realized whilst in sheep an expressed leukocytosis with neutrophilia was ascertained which is deemed important for the increase of antimicrobial protection. The results of the research of Tosevski et al. $(1999,2004)$ pointed out the fact that parenteral application of the extract of a whole plant of $H$. odorus W. et $\mathrm{K}$. can influence the metabolism of hepatocytes, muscular cells, cells of bone marrow and mastocytes (BTCbufaenolides target cells) and can provoke acceleration of metabolic processes in piglets and sheep. Bolte et al. (2001) proved that purified extract of Helleborus sp. can be effective in strenghtening postvaccinal immunological response in calves and bullcalves by activating both specific, as well as unspecific defensive 
Acta Veterinaria (Beograd), Vol. 60, No. 5-6, 605-618, 2010.

Davidović Vesna et al:: The effect of the extract of rhizome and

mechanisms. The same authors confirmed that purified extract of Helleborus sp. can provoke a modification of immuno response in cases of primary or secondary immunodeficiency, then can stimulate cellular multiplication, the activation of macrophages and releasing of IL-2, TNF and interferon.

An expressed leukocytosis and a positive effect on reproductive traits, fertility and number of live born piglets were determined after the extract of rhizome and root of $H$. odorus W. et $\mathrm{K}$. had been applied to gilts in the time of their sexual maturity (Ristoska et al., 2002). Milanović et al. (2004) studied the effect of the extract of the rhizome and root of $H$. odorus W. et $\mathrm{K}$. on the immuno system of Wistar strain rats and confirmed a significant leukocytosis and granulocytosis.

\section{MATERIAL AND METHOD}

The Wistar rats, male and female, at the age of 2 months, average body weight of about 200 grams, were divided into groups of 7 animals each. In order to determine the duration of the effect of the extract of hellebore rhizome and root $(\mathrm{HE})$, the trial animals were given intramuscularly, in the hind limb, a liquid extract of rhizome and root of hellebore in the concentration of $10 \mathrm{mg} / 100 \mathrm{~g} \mathrm{BW}$, while a blood sample was taken by cardiac puncture after 24h (Group II), 48h (Group III) and $72 \mathrm{~h}$ (Group IV). To the rats in the control group (Group I) a physiological solution in the quantity of $0.25 \mathrm{~mL} / 100 \mathrm{~g} \mathrm{BW}$, which corressponded to the volume of the applied extract of hellebore rhizome and root, was applied intramuscularly.

A grounded rhizome with roots of $H$. odorus $\mathrm{W}$. et $\mathrm{K}$. was extracted in the apparatus for a continual extraction according to Soxhlet dissolutions of arising polarity: petroleum ether, chloroform and methanol. The extracted plant material was then dried in a stream of cool air and afterwards extracted twice by water. By pairing the united water extracts a dry extract of yellow-ocher colour was obtained.

The parameter values of white blood count: count of total leukocytes (Le), count of neutrophil granulocytes (GR), percent of neutrophil granulocytes (GR\%), count of lymphocytes (Lym) and count of monocytes (Mo) were determined in full heparinised blood by means of a standard laboratory procedure on automatic haematologic analyser Arcus Diatron ${ }^{\circledR}, \mathrm{Gmbh}$ Wien, Austria. A neutrophillymphocytes index was calculated by means of the formula: $\mathrm{I}=$ (count of neutrophile granulocytes : count of lymphocytes) x 100 .

Determination of the degree of phagocytosis of residing (non-stimulated) peritoneal macrophages was carried out by means of HRP and phenol-red microtitre method according to Pick and Mizel (1981). A degree of phagocytosis of neutrophil granulocytes in full blood sample was determined by the test of phagocytosis of latex particles, a method according to Matusiewicz and Urbankowska (1991).

\section{RESULTS AND DISCUSSION}

During the trial, the count of total leukocytes in the blood of rats belonging to the control group was in the range of physiological limits and in accordance with 
reference values suggested by Moore (2000). A significant increase of leukocytes count after the application of HE was also similar to some literature citations. An average count of total leukocytes in the blood of control group of rats was $10.14 \pm 2.37 \times 10^{9} / \mathrm{L}$. In the blood of rats treated intramuscularly by hellebore extract (10 mg/100 g BW) an average value of total count of leukocytes was: $13.37 \pm 1.34 \times 10^{9} / \mathrm{L}$ after $24 \mathrm{~h}, 10.37 \pm 1.61 \times 10^{9} / \mathrm{L}$ after $48 \mathrm{~h}$ and $10.76 \pm 1.34 \times$ $109 / \mathrm{L}$ after $72 \mathrm{~h}$. A trial group to which HE was applied had a greater count of leukocytes after $24 \mathrm{~h}$ in relation to control group (FR) by $31.85 \%$, what is statistically significant at the level of $p<0.01$. An increased count of leukocytes was also recorded $48 \mathrm{~h}$ and $72 \mathrm{~h}$ after treatment of rats by $\mathrm{HE}$, but those differences were not statistically significant in relation to the control group, whilst in relation to the value determined after $24 \mathrm{~h}$ the count of leukocytes was significantly lower $(p<0.01)$ (Figure 1)

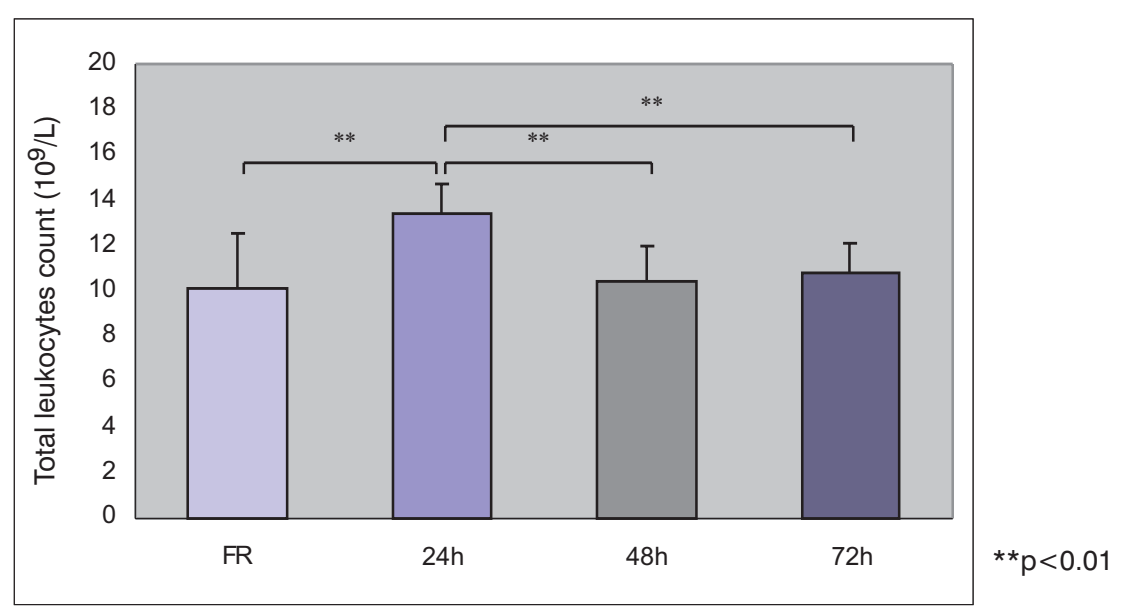

Figure 1. Total leukocytes count $\left(10^{9} / \mathrm{L}\right)$

A pronounced leukocytosis was also noticed by Bogdan et al. (1989, 1990a) $24 \mathrm{~h}$ after transcutaneous implantation of rhizome of Helleborus sp. in cattle necklace, horses chest skin and sheep and pigs auricle. An insignificant increase in the number of total leukocytes in the blood of rats $48 \mathrm{~h}$ and $72 \mathrm{~h}$ after application of $\mathrm{HE}$ is in accordance with the results obtained by these authors by studying the count of leukocytes $48 \mathrm{~h}, 96 \mathrm{~h}$ and $144 \mathrm{~h}$ after the implantation of hellebore rhizome to all species of animals. Comparing the effects obtained in sheep by implantation of rhizome $H$. purpurascens $L$. and injecting 3 variants of $H$. purpurascens $L$, Bogdan et al. (1990-b) confirmed that the most pronounced leukocytosis was observed $24 \mathrm{~h}$ after the implantation of rhizome, the order of efficiency being as follows: $4 \%$ extract of saponosides, $4 \%$ decoction and $1 \%$ odecoction. An inflammatory reaction manifested by an occurrence of oedema and spotted bleedings at the place of injection, was perceived in rats $24 \mathrm{~h}$ after intramuscular 
Acta Veterinaria (Beograd), Vol. 60, No. 5-6, 605-618, 2010.

Davidović Vesna et al.: The effect of the extract of rhizome and

application of the extract of Helleborus sp. (Bolte et al., 1992). Tosevski et al. $(1999,2004)$ recorded, after the application of extract of Helleborus odorus W. et $\mathrm{K}$. to piglets in the age of 35 days and 52 days, a significant increase in the leukocytes count in the blood after 7, 14 and 21 days. A determined increase in the count of total leukocytes $24 \mathrm{~h}$ after treatment of rats by $\mathrm{HE}$ in our trial is similar to the increase of this value stated by Milanović et al. (2004). In the trial on Wistar rats by the application of water extract of hellebore diluted by saline solution in proportion of 1:2 this author also registered a significant leukocytosis. High values in the count of total leukocytes after HE application can be compared with the results of Ristoska et al. (2002) who, after the application of the extract of hellebore to gilts, also recorded a significant increase in the value of the count of total leukocytes in relation to reference values.

Treatment with aqueous extract of Boerhaavia diffusa Linn. (Nyctaginaceae) also has been shown to induce leukocytosis with predominant neutrophilia (Mungantiwar et al., 1997).

Pritchett and Corning (2004) suggest the limit of $1.3-3.6 \times 10^{9} / \mathrm{L}$ as reference values in the count of neutrophil granulocytes in the blood of rats. In our trial, count of neutrophil granulocytes in the blood of rats of control group was $2.49 \pm 0.54 \times 10^{9} / \mathrm{L}$, what is in accordance with the values suggested by these authors. In all trial groups in which the effect of HE during the time periods $(24 \mathrm{~h}$, $48 \mathrm{~h}$ i $72 \mathrm{~h}$ ) was monitored on the modifications in the count of neutrophil granulocytes in the blood of rats a greater value in relation to the control group was registered. Mean values as regards the count of neutrophil granulocytes in the blood of rats given the hellebore extract were as follows: $6.43 \pm 0.80 \times 10^{9} / \mathrm{L}$ after $24 \mathrm{~h}, 2.86 \pm 1.51 \times 10^{9} / \mathrm{L}$ after $48 \mathrm{~h}, 2.55 \pm 0.36 \times 10^{9} / \mathrm{L}$ after $72 \mathrm{~h}$. A statistically highly significant difference was confirmed only between a control group and $24 \mathrm{~h}$ after application of HE $(p<0.001)$. In this group the count of neutrophil granulocytes was higher by $158.23 \%$. A statistically significantly higher value in the count of neutrophil granulocytes in blood was recorded $24 \mathrm{~h}$ post-treatment in relation to other two trial groups $(p<0.001)$, among which a statistical significance was not recorded (Figure 2).

An average percent of neutrophil granulocytes in the blood of the control group of rats was $25.01 \pm 4.80$, what is within the limits of reference values which according to Moor (2000) for this category of rats are: $16.6 \pm 5.7 \%$ (males) and $15.3 \pm 5.7 \%$ (females). A percent of neutrophil granulocytes in the blood of the trial rats in which the effect of $\mathrm{HE}$ was monitored during the time periods was from $48.09 \%$ (after $24 \mathrm{~h}$ ) being statistically significant in relation to the control group of animals ( $p<0.001$ ), to $26.53 \%$ (after $48 \mathrm{~h}$ ) and $23.77 \%$ (after $72 \mathrm{~h}$ ) which represent a statistically not significant difference in relation to the control group. The values regarding the percent of neutrophil granulocytes in the blood of the group $24 \mathrm{~h}$ after application of $\mathrm{HE}$ was significantly higher in relation to other trial groups $(p<0.001)$, among which a statistical significance was not confirmed (Figure 3$)$. 


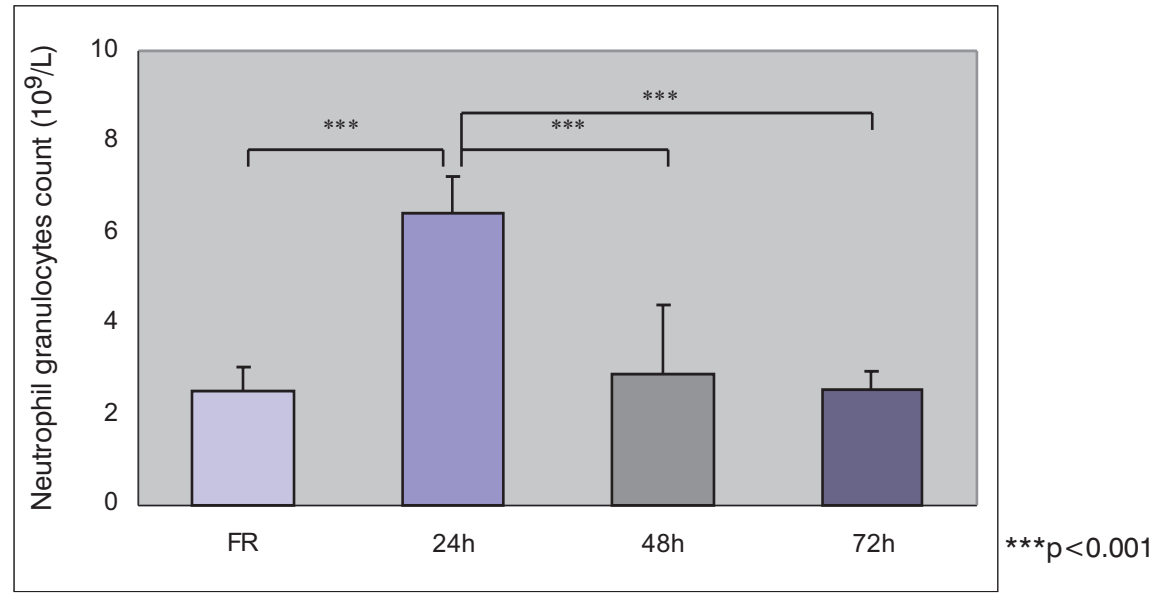

Figure 2. Neutrophil granulocytes count (109/L)

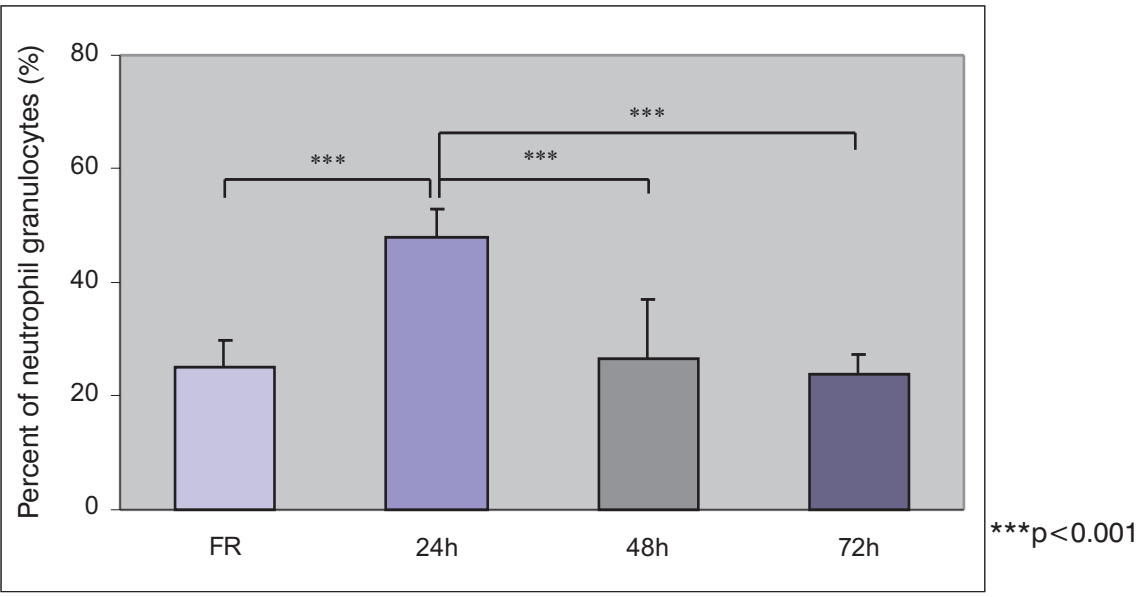

Figure 3. Percent of neutrophil granulocytes (\%)

Our results correspond to the results of a greater number of authors who also recorded an increase in count and percent of neutrophil granulocytes in the blood of animals treated by HE. Bogdan et al. (1989, 1990-a, 1990-b, 1993) determined a significant increase in the count and percent of neutrophil granulocytes in a number of animal species (cattle, horses, pigs and sheep) $24 \mathrm{~h}$ post-implantation of rhizome or application of the extract of hellebore. However, different to our research they registered a significant increase of neutrophil granulocytes after $48 \mathrm{~h}, 96 \mathrm{~h}$ and $144 \mathrm{~h}$ as well. This could be explained by differences in the applied doses and mode of extraction. The authors also 
Acta Veterinaria (Beograd), Vol. 60, No. 5-6, 605-618, 2010.

Davidović Vesna et al.: The effect of the extract of rhizome and

perceived the modification in blood count relationship in some types of leukocytes in the leukocyte formula, in favour of neutrophil granulocytes whose mobilisation was stimulated the most. Granulocytosis, suggested by Milanović et al. (2004), after the application of HE water solution diluted by saline solution in proportions 1:2, 1:4 and 1:8 and applied to rats also coressponds to our results.

Our results are similar to those stated by Bolte et al. (1992) who studied immunostimulatory effects of $\mathrm{HE}$ in calves. The experiment which Bolte et al. (2001) some time later repeated on calves and bullcalves confirmed a significant increase in the count and percent of neutrophil, eozinophil and bazophil granulocytes on 7, 14 and 21 days after the application of HE. Tosevski et al. $(1999,2004)$ recorded a significant increase in the count and percent of neutrophil granulocytes in the blood of piglets at the age of 35 days on 7 and 14 days after the application of $\mathrm{HE}$, and in piglets at the age of 52 days on 14 and 21 day after the HE treatment. These results differ from ours only in the fact that the effect we have perceived was short-lived. Ristoska et al. (2002) reported that $24 \mathrm{~h}$ after the application of $\mathrm{HE}$ to gilts the count and percent of neutrophil granulocytes remains within the limits of reference values, which is in contrast to the results of our research.

In the course of the trial the mean values in the count of limphocytes in the blood of examined rats ranged from $6.05 \times 10^{9} / \mathrm{L}$ ( $24 \mathrm{~h}$ after application of $\left.\mathrm{HE}\right)$ to $7.38 \times 10^{9} / \mathrm{L}(72 \mathrm{~h}$ after the application of $\mathrm{HE})$ and were within the physiological limits (5.6-8.3 $\left.\times 10^{9} / \mathrm{L}\right)$ suggested by Pritchett and Corning (2004). The value in the limphocytes count in the blood of rats of the control group was lower only in relation to the limphocytes count recorded in the group $72 \mathrm{~h}$ after application of $\mathrm{HE}$, whilst in other trial groups the limphocytes count was higher, although determined differences were not significant. At the expiration of $72 \mathrm{~h}$ after the application of HE a significantly higher count of limphocytes in relation to the group of $24 \mathrm{~h}$ after application of HE $(p<0.05)$ was recorded. The lowest value in the count of limphocytes $24 \mathrm{~h}$ after application of $\mathrm{HE}$ is proportional to the increase in the count of neutrophil granulocytes which is most pronounced in this group (Figure 4).

The results obtained $24 \mathrm{~h}$ and $48 \mathrm{~h}$ after the treatment with $\mathrm{HE}$ correspond to the results of Ristoska et al. (2002) who also determined that the count of limphocytes remains within the limits of reference values $24 \mathrm{~h}$ after the application of $\mathrm{HE}$ to gilts. A significant increase in the count of lymphocytes $72 \mathrm{~h}$ after the application of HE to rats is partly in accordance with the results of Tosevski et al. $(1999,2004)$ who established that the application of HE to piglets at the age of 35 days caused an increase in the count of lymphocytes by $87 \%$ after 7 days and by $83 \%$ after 14 days in relation to the recorded value before $\mathrm{HE}$ application. It is interesting to note the observation of Tosevski et al. (2004) that in piglets at the age of 52 days the same dose and the same mode of application of HE as in previous studies brought about no change in the value regarding the count of lymphocytes and it has remained the same although somewhat reduced at day 14 and day 21 of the experiment.

Dirsch et al. (1993) confirmed that hellebrin, $\beta$-ecdysone and $5 \alpha$ hydroxyecdysone from $H$. purpurascens $\mathrm{W}$. et $\mathrm{K}$. can produce supreme 
proliferation of lymphocytes whilst a steroid saponine can have a stimulating effect therein. In vitro applied water extract of $H$. niger L. in different concentrations can influence immunocompetent cells in such a way that they induce the exchange of sister chromatides (SCE) in the culture of peripheral blood mononuclear cells (PBMC) of healthy persons and provoke the proliferation of isolated lymphocytes (Büsing and Schweizer, 1998).

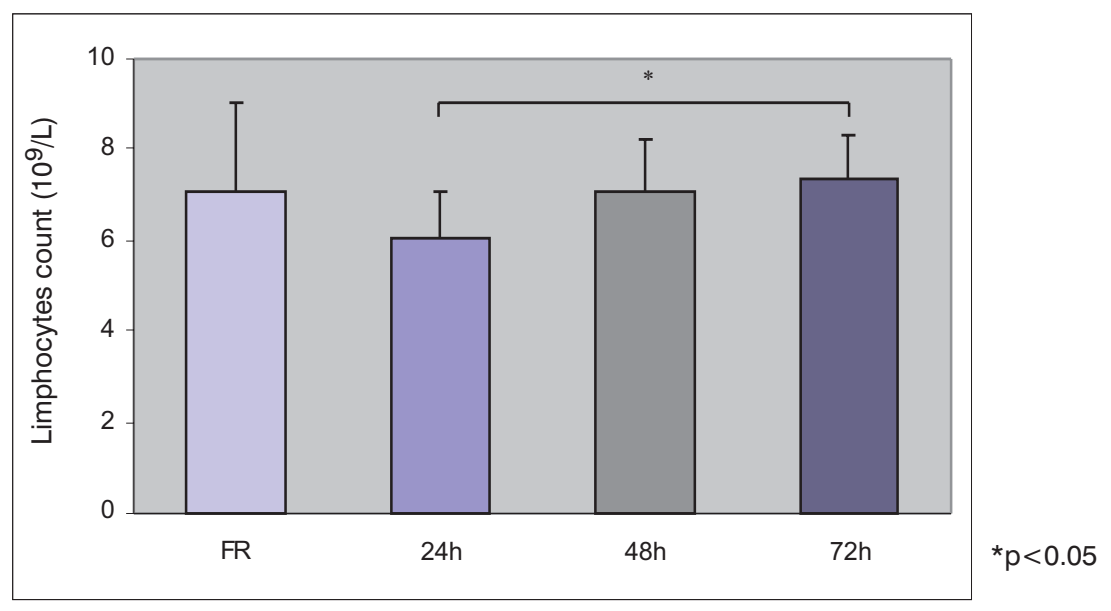

Figure 4. Limphocytes count (109/L)

In all trial groups treated with hellebore extract except for the group at $72 \mathrm{~h}$ after application of $\mathrm{HE}$, the increase in neutrophil/limphocyte index, in relation to the control group in which Ne/Lym index was $37.17 \pm 11.66$, was observed. The highest confirmed $\mathrm{Ne} / \mathrm{Lym}$ index was registered 24h after application of HE $(109.22 \pm 24.24)$, and it was higher by $193.84 \%$ in relation to the control group $(p<0.001)$. A difference in the average value of $\mathrm{Ne} / \mathrm{Lym}$ index $24 \mathrm{~h}$ after treatment with $\mathrm{HE}$ in relation to other trial groups was statistically significant $(p<0.001)$ (Figure 5).

In the available literature data we found no records regarding the values of $\mathrm{Ne} / \mathrm{Lym}$ index after the application of $\mathrm{HE}$ or implantation of Helleborus L rhizome.

A number of monocytes in the blood of the control group rats was $0.57 \times 10^{9} / \mathrm{L}$, whilst in the blood of trial animals this value ranged from $0.48 \times 10^{9} / \mathrm{L}$ to $0.93 \times 10^{9} / \mathrm{L}$. A determined difference in mean values in the count of monocytes was not statistically significant, neither between the control group and groups $24 \mathrm{~h}, 48 \mathrm{~h}$ and $72 \mathrm{~h}$ after application of $\mathrm{HE}$, nor among the self same groups treated by HE in the course of time period (Figure 6).

The absence of statistical significance in the examined groups of rats during the trial is in accordance with the results obtained on piglets at the age of 35 days (Tosevski et al., 1999, 2004). Ristoska et al. (2002) established a very pronounced monocytosis $24 \mathrm{~h}$ and $48 \mathrm{~h}$ after the application of HE to gilts. Tosevski et al. (2004) 
Acta Veterinaria (Beograd), Vol. 60, No. 5-6, 605-618, 2010.

Davidović Vesna et al.: The effect of the extract of rhizome and

root of hellebore (Helleborus odorus W. et K.) on parameters

of white blood count and degree of phagocytosis in Wistar rats

also noted an increase in the count of monocytes in piglets at the age of 52 days being 1.4 times higher 14 days after the application of $\mathrm{HE}$ and by 1.2 times higher at day 21 . of trial.

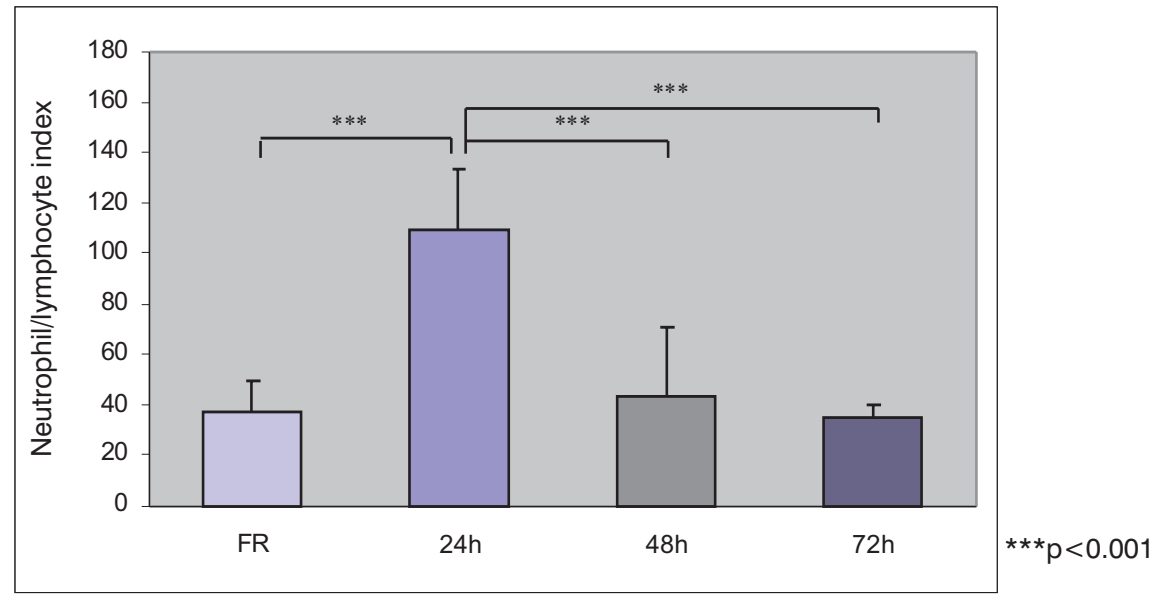

Figure 5. Neutrophil/lymphocyte index

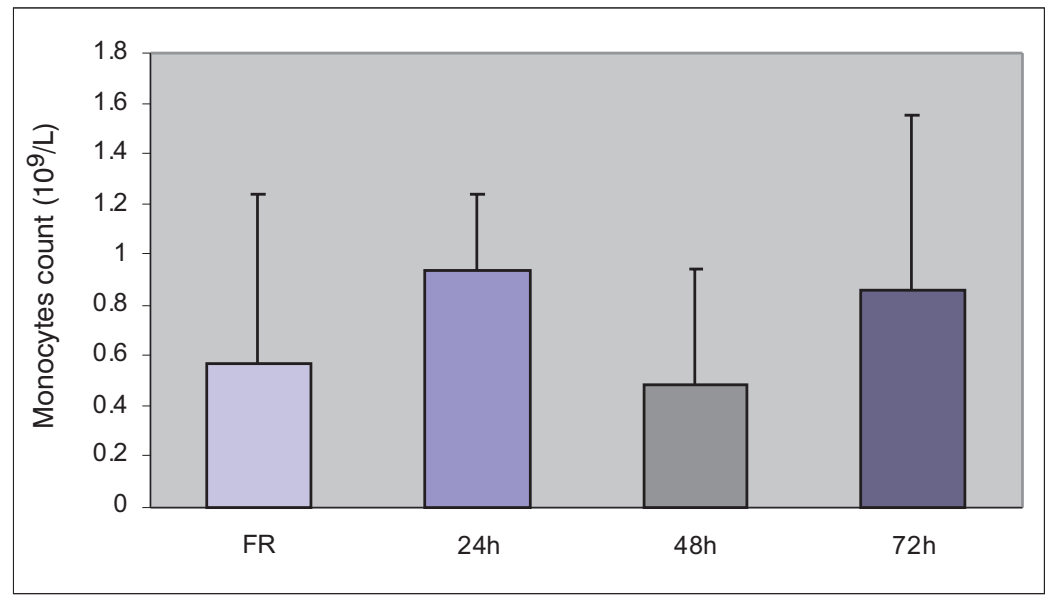

Figure 6. Monocytes count (109/L)

A research on the degree of phagocytosis of residing (non-stimulated) peritoneal macrophages, by determining the level of production of $\mathrm{H}_{2} \mathrm{O}_{2}$ was conducted $24 \mathrm{~h}$ after the intramuscular application of sterile physiological solution (FR) to a control group of rats and application of $\mathrm{HE}(10 \mathrm{mg} / 100 \mathrm{~g} \mathrm{BW})$ to a trial 
group. The average $\mathrm{H}_{2} \mathrm{O}_{2}$ concentration values ( $\mathrm{nM} / \mathrm{mg}$ protein) after the stimulation of macrophages by different concentrations of PMA in the control group of rats ranged from 12.80 (after stimulation with $0 \mathrm{nM} P M A$ ) to 38.74 that is 32.36 (after stimulation with $25 \mathrm{nM}$ PMA ie. $50 \mathrm{nM}$ PMA). In the trial group of rats $24 \mathrm{~h}$ after the application of $\mathrm{HE}$, after stimulation of macrophages by different concentrations of PMA, the values ranged from 6.29 (after stimulation with $0 \mathrm{nM}$ $\mathrm{PMA}$ ) to 88.53 (after stimulation with $50 \mathrm{nM}$ PMA). These results suggest a dosedependent trend in the production of $\mathrm{H}_{2} \mathrm{O}_{2}$ depending on the concentration of PMA, reaching the "plateau" values at the concentration of $25 \mathrm{nM}$ in the control group and $50 \mathrm{nM}$ in the trial group of rats.

A significantly higher production of $\mathrm{H}_{2} \mathrm{O}_{2}(\mathrm{nM} / \mathrm{mg}$ proteins) created by macrophages after stimulation by $0 \mathrm{nM}$ PMA was recorded in the control group in relation to the groups to which HE was applied, the level of significance being $p<0.01$. The difference in mean values in the concentrations of $\mathrm{H}_{2} \mathrm{O}_{2}(\mathrm{nM} / \mathrm{mg}$ proteins) created by macrophages was not statistically significant between the control and trial groups after stimulation of macrophages with 6 nM PMA. Statistically significant differences $(p<0.05)$ were confirmed after stimulating the production of $\mathrm{H}_{2} \mathrm{O}_{2}$ (nM/mg proteins) by macrophage with $12.5 \mathrm{nM}$ PMA, $25 \mathrm{nM}$ PMA and $50 \mathrm{nM}$ PMA, whereas in all cases a significantly greater concentration was established in the group of rats to which $\mathrm{HE}$ was applied in relation to the control group (Figure 7).

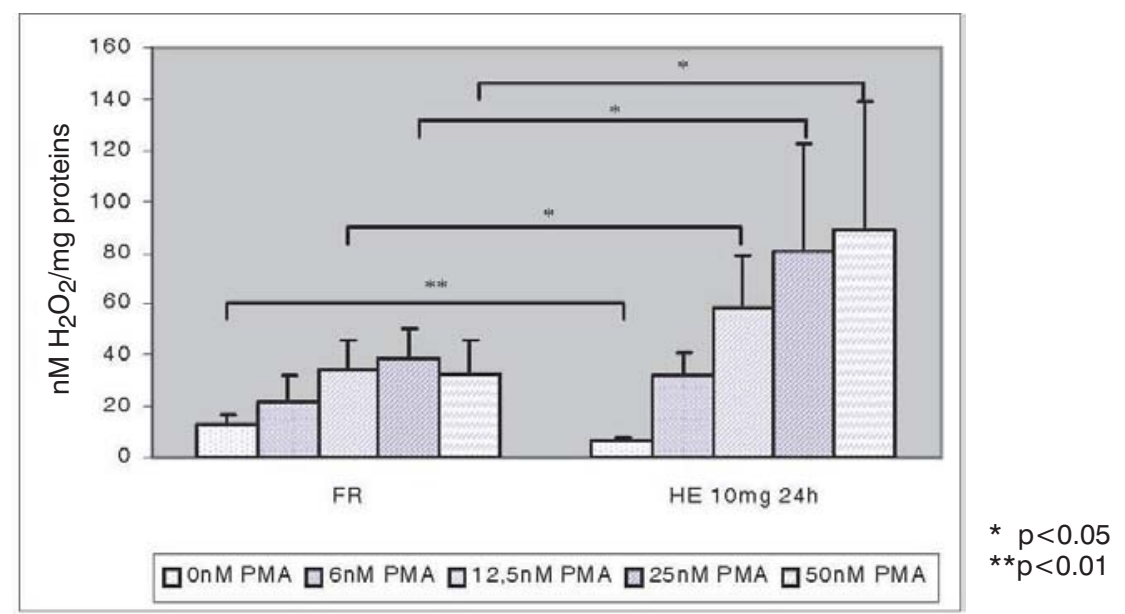

Figure 7. Concentration of $\mathrm{H}_{2} \mathrm{O}_{2}$ (nM/mg proteins) created by residing (non-stimulated) peritoneal macrophages

On the basis of these records it can be concluded that the treatment of rats with the extract of rhizome and root of hellebore has led to a significant increase in the production of $\mathrm{H}_{2} \mathrm{O}_{2}$ by residing peritoneal macrophages. Analysing a highly purified extract of $H$. purpurascens W. et K. (HP 12) Kerek (1997) confirmed that it 
Acta Veterinaria (Beograd), Vol. 60, No. 5-6, 605-618, 2010.

Davidović Vesna et al.: The effect of the extract of rhizome and

has a stimulatory influence on rats' macrophages. Also, the application of the aqueous extract of Boerhaavia diffusa Linn. (Nyctaginaceae) to Swiss albino mice has resulted in the stimulation of the phagocytic and bactericidal capacity of macrophages and neutrophil granulocytes (Mungantiwar et al., 1997). Different immunoactive plant polysaccharides can activate neutrophils and macrophages and enhance secretion of pro-inflammatory mediators such as cytokines, eicosanoids and enzymes. Pectic polysaccharides from Selene vulgaris (Caryophyllaceae) and galactomannan from Trigonella foenum-graecum (Fabaceae) were shown to increase the uptaking capacity of rat peritoneal resident macrophages (Schepetkin and Quinn, 2006). Oral administration of Echinacea extracts resulted in increased phagocytic activity of rats' alveolar macrophages and increased phagocytic index (Goel et al., 2002).

A research on the degree of phagocytosis of neutrophil granulocytes by determining the phagocyte index was carried out $24 \mathrm{~h}$ after intramuscular application of sterile physiological solution to a control group of rats and application of HE (10 mg/100 g BW) to a trial group. A significantly higher percent $(p<0.05)$ of neutrophil granulocytes containing at least 3 granules of latex particles in rats to which HE was applied $(30.04 \pm 6.29)$ in relation to the rats in the control group (23.76 \pm 2.89$)$ was recorded (Figure 8).

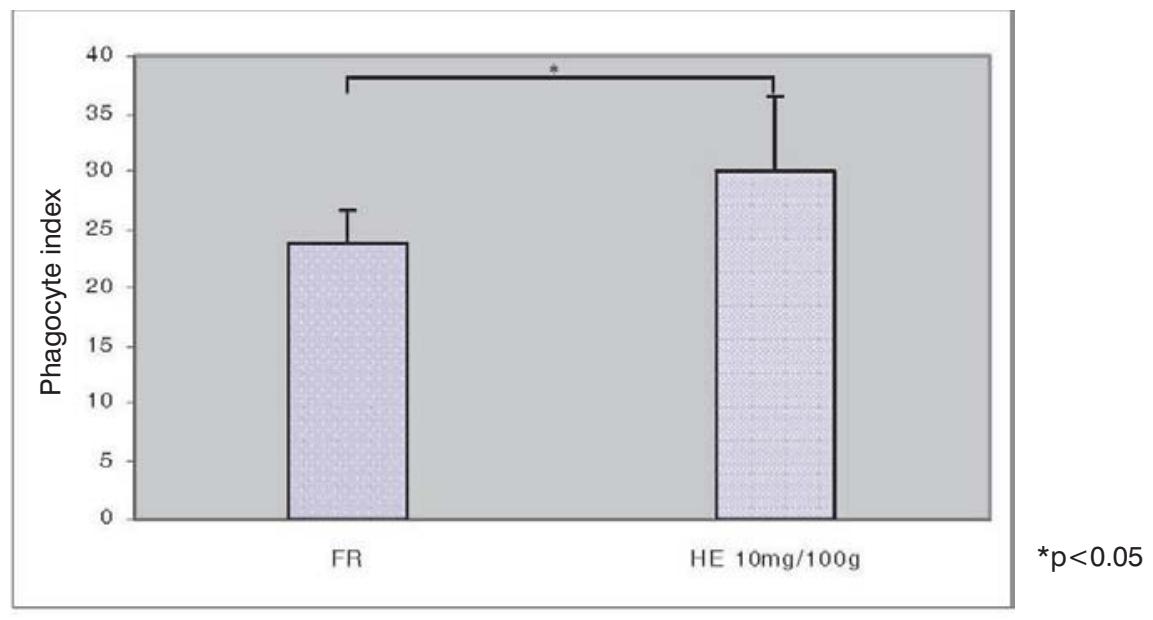

Figure 8. Phagocyte index of neutrophil granulocytes

Our results obtained on rats correspond to the results of Bogdan et al. $(1989,1990-a)$. These authors say that the index of phagocytosis in sheep was 021 before the implantation of rhizome of Helleborus L. and 0-34 after the implantation. It means that under the influence of the implans of hellebore the value of an overall capacity of phagocytosis of neutrophil granulocytes has increased more than 6 times in relation to the value before the implantation. The determined difference was statistically significant after $48 \mathrm{~h}(p<0.01)$. 
It can be assumed that the immunostimulatory influence of $\mathrm{HE}$ is realized by at least three mechanisms: by increasing the count of leukocytes, by increasing the count of neutrophil granulocytes and by stimulating the phagocytosis by neutrophil granulocytes and macrophages.

Address for correspondence:

Davidović Vesna

Faculty of Agriculture

Nemanjina 6

11070 Zemun, Serbia

E mail: vesnadv@agrif. bg.ac.rs

\section{REFERENCES}

1. Bogdan I, Basea I, Nechifor A, Hruban E, 1989, Cercetari privind efectul implantului de spin (Helleborus purpurascens L.) la bovine, cabaline, ovine si porcine, Buletin IACN, ZMV, 43, 6772.

2. Bogdan I, Nechifor A, Basea I, Hruban E, 1990-a, Aus der rumänischen Volksmedizin: Unspezifische Reiztherapie durch transkutane implantation der Nieswurz (Helleborus purpurascens, Fam. Ranunculaceae) bei landwirtschaftlichen Nutztieren, Dtsch Tierärztl Wschr, 97, 12, 525-9.

3. Bogdan I, Nechifor A, Ghitulescu C, 1990-b, Experimentarea a trei variante de extract injectabil de spînz (Helleborus purpurascens, fam. Ranunculaceae) la ovine, Simpozionul Actualitati in patologia animalelor, Cluj-Napoca, XVII, 31-44.

4. Bogdan I, Hruban E, Nueleanu V, Bogdan A, 1993, Certari privind eficacitatea extractului injectabil de spinz (Helleborus purpurascens) in hipotrepsia mieilor, Buletin USA Cluj-Napoca seria Zootehnie si med vet, 47, 143-9.

5. Bolte $S$, Trif $R$, Susa I, Igna $C, 1992$, Terapia proinflamatorie si imunostimulanta cu extracte de Helleborus species, Lucrari stiintifice med vet, XXVI, Timisoara, 152-5.

6. Bolte S, Petrut H, Trif R, 2001, Imunostimularea cu extract de Helleborus spp., Lucrari stiintifice med vet, XXXIV, Timisoara, 79-86.

7. Büssing A, Schweizer K, 1998, Effects of a phytopreparation from Helleborus niger on immunocompetent cells in vitro, $J$ Ethnopharmacol, 59, 3, 139-46.

8. Colombo ML, Tomè F, Bugatti C, 1991, Lipid content and fatty acid composition in hypogeous organs of Helleborus species (Ranunculaceae), PI Syst Evol, 178, 55-63.

9. Colombo ML, Tomè F, 1993, Ecdysteroid Production in Helleborus odorus ssp. laxus: Response to Different Environments, Int J Pharmacogn, 31, 4, 311-5.

10. Dirsch V, Lacaille-Dubois MA, Wagner $H, 1993$, Search for the antirheumatic principle in the roots of Helleborus purpurascens, Planta Medica, 59 (Supplement), A586.

11. Goel V, Chang C, Slama JV, Barton R, Bauer R, Gahler R, Basu TK, 2002, Echinacea stimulates macrophage function in the lung and spleen of normal rats, $J$ Nutrit Biochem, 13, 487-92.

12. Kerek F, 1997, Offenlegungsschrift, Patentnummer: DE 19600301 A1, Bioregulatorischer Wirkstoff, Verfahren zu seiner Herstellung sowie dessen Verwendung, Deutsches Patentamt, München, Germany.

13. Makare N, Bodhankar S, Rangari V, 2001, Immunomodulatory activity of alcoholic extract of Mangifera indica L. in mice, J Ethnopharmacol, 78, 133-7.

14. Matusiewicz R, Urbankowska B, 1991, The ability of granulocytes to engulf latex particles and Staphylococcuc aureus in healthy children of parents with infectious asthma, $J$ Invest Allergol Clin Immunol, 1, 125-8.

15. Milanović S, Lazarević M, Jovanović M, 2004, Effects of root extract from Helleborus odorus on rats immune system, $6^{\text {th }}$ Symposium in veterinary clinical pathology and therapy animals with international participation improvement, Budva, Clinica veterinaria, 355-7. 
Acta Veterinaria (Beograd), Vol. 60, No. 5-6, 605-618, 2010.

Davidović Vesna et al.: The effect of the extract of rhizome and

16. Moore MD, 2000, Chapter 189: Hematology of the Rat (Rattus norvegicus) in Feldman FB et al.: Fifth edition Schalm's Veterinary Hematology, Copyright (C) 2000 Lippincott Williams \& Wilkins.

17. Muhr P, Kerek F, Dreveny D, Likussar W, Schubert-Zsilavecz M, 1995, The structure of hellebrin, Liebigs Annalen, 2, 443-4.

18. Mungantiwar AA, Nair AM, Saraf MN, 1997, Adaptogenic activity of aqueous extract of the roots of Boerhaavia diffusa Linn, Indian Drugs, 34, 184.

19. Pick E, Mizel D, 1981, Rapid microassays for the measurement of superoxide and hydrogen peroxide production by macrophages in culture using an automatic enzyme immunoassay reader, $J$ Immunol Meth, 46, 211-26.

20. Pritchett KR, Corning BF, 2004, Biology and Medicine of Rats, In: Laboratory Animal Medicine and Management, Reuter JD and Suckow MA (Eds.), International Veterinary Information Service, Ithaca NY (www.ivis.org).

21. Ribár B, Kapor A, Vladimirov S, Živanov-Stakić D, Argay G, Kálmán A, 1986, Structure of Spirosta5,25(27)-diene-3 $\beta, 11 \alpha$-diol, Acta Cryst, C42, 1780-2.

22. Ristoska D, Ristoski T, Tosevski J, Ulčar I, 2002, Use of the Helleborus odorus extract in early detection of pathological conditions in pig production, 20th Meeting of the European Society of Veterinary Pathology, Grugliasco (Turin) Italy, 215.

23. Rosselli S, Maggio A, Bruno M, Spadaro V, Formisano C, Irace C, Maffettone C, Mascolo N, 2009, Furostanol Saponins and Ecdysones with Cytotoxic Activity from Helleborus bocconei ssp. intermedius, Phytother Res, DOI: 10.1002/ptr. 2569.

24. Schepetkin IA, Quinn MT, 2006, Botanical polysaccharides: Macrophage immunomodulation and therapeutic potential, Internat Immunopharmacol, 6, 317-33.

25. Slavik J, Bochoráková J, Slaviková L, 1987, Occurrence of magnoflorine and corytuberine in some wild or cultivated plants of Czechoslovakia, Collection Czechoslovak Chem Commun, 52, 804 12.

26. Tosevski J, Stojkovski V, Ulčar I, 1999, Determination of temperature coefficient in swine by using Helleborus odorus extract, XXIV sredba "Fakultet - stopanstvo" '99, 7, Skopje, Zbornik na trudovi, 177-89.

27. Tosevski J, Ulčar I, Hajrulai-Musliu Z, Ristoska D, Lončarević A, 2004, Use of plant mitogenic compounds in veterinary practice, $6^{\text {th }}$ Symposium in veterinary clinical pathology and therapy animals with international participation improvement, Budva, Clinica veterinaria, 100-6.

28. Tucakov J, 1996, Lečenje biljem, Rad, Beograd

29. Vladimirov S, Živanov-Stakić D, Ribár B, 1991, A steroidal sapogenin from Helleborus multifidus subsp. serbicus, Phytochemistry, 30, 5, 1724-5.

30. Wissner W, Kating H, 1974, Botanische und phytochemische untersuchungen an den Europäischen und Kleinasiatischen arten der gattung Helleborus, II. Vergleichende phytochemische Untersuchungen der Herzglykosid- und Saponin- Führung, Planta Medica, 26, 228-49.

UTICAJ EKSTRAKTA RIZOMA I KORENA KUKUREKA (HELLEBORUS ODORUS W. ET K.) NA PARAMETRE BELE KRVNE SLIKE I STEPEN FAGOCITOZE KOD WISTAR PACOVA

\author{
DAVIDOVIĆ VESNA, LAZAREVIĆ M, JOKSIMOVIĆ-TODOROVIĆ MIRJANA, \\ MAKSIMOVIĆ Z i JOVANOVIĆ M
}

\title{
SADRŽAJ
}

Cilj ovog rada je bio da se ispita uticaj ekstrakta rizoma $i$ korena $H$. odorus $\mathrm{W}$. et $\mathrm{K}$. na promenu vrednosti parametara bele krvne slike i stepen fagocitoze od 
strane peritonealnih makrofaga i neutrofilnih granulocita kod pacova soja Wistar. Ogled je izveden na 28 pacova podeljenih u 4 grupe po 7 jedinki. Kontrolnoj grupi pacova je intramuskularno aplikovan sterilan fiziološki rastvor u količini od $0,25 \mathrm{ml} / 100 \mathrm{~g} \mathrm{TM}$. U cilju praćenja efekta ekstrakta rizoma i korena kukureka (EK) u toku vremena, pacovima je intramuskularno aplikovan EK u dozi od $10 \mathrm{mg} / 100 \mathrm{~g}$ TM, a krv za analizu je uzimana posle $24 \mathrm{~h}, 48 \mathrm{~h}$ i $72 \mathrm{~h}$.

Intramuskularna aplikacija EK imala je za posledicu povećanje broja ukupnih leukocita u svim oglednim grupama, pri čemu je najizraženija leukocitoza registrovana 24h nakon aplikovanja EK. Statistički značajno veća vrednost broja i procenta neutrofilnih granulocita u krvi zabeležena je $24 \mathrm{~h}$ posle tretmana u odnosu na kontrolnu i ostale dve ogledne grupe $(p<0,001)$, između kojih nije utvrđena statistička značajnost. Ekstrakt rizoma i korena kukureka doveo je do nastanka limfopenije, što je imalo za posledicu povećanje neutrofilno/limfocitnog indeksa u oglednim grupama $24 \mathrm{~h}$ i $48 \mathrm{~h}$ nakon tretmana. Aplikacija EK nije značajno uticala na broj monocita kod tretiranih životinja. Upotrebljeni ekstrakt doveo je do značajnog povećanja stepena fagocitoze od strane rezidentnih peritonealnih makrofaga i neutrofilnih granulocita krvi. 